\title{
STRUKTURA KAPITALA KAO DETERMINANTA
}

\section{VREDNOSTI PREDUZEĆA}

\author{
Nikola Milanović ${ }^{43}$, Slobodan Andžić ${ }^{44}$, Mirko Butulija ${ }^{45}$
}

Stručni rad

UDK: 330.14

005.52:330.133.7

\section{Apstrakt}

Profit predstavlja osnovni cilj svakog proizvodnog preduzeća. Da bi neko preduzeće moglo da proizvede proizvod, ili pruži uslugu, ono mora raspolagati određenim kapitalom. Postoje dve vrste kapitala i potrebno je utvrditi pravi odnos između njih, kako taj odnos utiče na poslovanje preduzeća, njegov profit i njegovu vrednost. To će biti naš cilj u ovom radu. Izvršićemo analizu jednog proizvodnog preduzeća. Na osnovu njegovih finansijskih izveštaja, a koristeći se metodom poređenja, uporedićemo ključne parametre koji će nam omogućiti da stignemo do potrebnih informacija $i$ postavljenog cilja.

Ključne reči: preduzeće, sopstveni kapital, pozajmljeni kapital, finansijski rizik, dobitak, stopa prinosa.

\section{Uvod}

U kapitalističkom periodu, gde se trenutno nalazi privreda naše zemlje i gde preovladava pretežno bankocentrično tržište, gotovo je nemoguće zamisliti poslovanje preduzeća bez pozajmljenih izvora, odnosno bez kredita. Osnovni cilj menadžmenta preduzeća jeste ponaći optimalan odnos sopstvenih i pozajmljenih izvora finansiranja koja će uticati na maksimiziranje profita. Naš zadatak biće da istražimo u kojoj meri odnos između sopstvenog i pozajmljenog kapitala utiče na poslovanje preduzeća i njegovu tržišnu vrednost?

\footnotetext{
43 Nikola Milanović, Univerzitet odbrane, Vojna akademija, Beograd, Generala Pavla Jurišića Šturma br. 33, Beograd, E-mail: office@va.mod.gov.rs

${ }^{44}$ Profesor, dr Slobodan Andžić, Beogradska poslovna škola, Ulica Kraljice Marije br. 76, Beograd, E/mail: s.andzic@bbs.edu.rs

${ }^{45}$ Mirko Butulija, AMS Osiguranje, Beograd, Ulica Ruzveltova br. 16
} 


\section{Kapital preduzeća}

Preduzeće predstavlja osnovnu poslovnu jedinicu svakog privrednog sistema. Ona se osnivaju radi obavljanja odeđene delatnosti. Da bi preduzeća mogla da obavljaju funkciju zbog kojih su osnovana, ona moraju da raspolažu određenim sredstvima, odnosno kapitalom. Najčešće se ta sredstva javljaju u novčanom obliku, tako da se obezbeđenje sredstava koja su potrebna za osnivanje preduzeća najčešće javljaju kao pribavljenje novčanih sredstava. (Milojević 2010:198)

$\mathrm{Na}$ osnovu porekla novčanih sredstava, kapital možemo posmatrati kroz sopstvene izvore kapitala i pozajmljene izvore kapitala. Sopstveni kapital predstavlja kapital koji pripada samo preduzeću, odnosno njihovim vlasnicima. Oni se sastoje iz osnovnog kapitala, rezervi i neraspoređene dobiti. U zavisnosti od organizacije preduzeća osnovni kapital može biti: akcijski, društveni, državni u obliku udela i u obliku uloga.

\section{Struktura kapitala preduzeća}

Osim izbora načina finansiranja preduzeća, finansijski menadžment definiše i strukturu finansiranja preduzeća. Organski sastav kapitala u preduzeću je zapravo odnos sopstvenog i tuđeg kapitala, izražena je u pasivi bilansa stanja i ozačava se kao finansijska struktura preduzeća. (Milojević 2010:198)

Elementi strukture kapitala su:

- Sopstveni kapital

- Dugoročni pozajmljeni kapital

Sopstveni kapital preduzeća čini kapital od emisije običnih akcija i akumulirani dobitak. Treba imati u vidu da je sopstveni kapital uži pojam od sopstvenih izvora koji obuhvataju i izdvajanja na ime amortizacije. Naknade na ime amortizacije ne predstaljaju povećanje poslovnih sredstava koje nužno prati povećanje neke od pozicija bilansa stanja.

Kapital od emisije običnih akcija se formira emisijom i prodajom običnih akcija na tržištu hartija od vrednosti i smatra se sopstvenim trajnim izvorom finansiranja preduzeća. Akcije imaju svoju nominalnu vrednost koja se utvrđuje ugovorom o osnivanju preduzeća, odnosno odlukom akcionara. Broj prodatih i uplaćenih akcija opredeljuje knjigovodstvenu vrednost akcijskog kapitala koji se javlja u pasivi bilansa stanja preduzeća.

Akumulirani dobitak se može definisati kao sopstveni kapital preduzeća koji je nastao reinvestiranjem dela neto dobiti u poslovanje preduzeća. U preduzeću 
koje vodi računa o svom rastu, ukupan iznos neto dobitka ne može biti isplaćen akcionarima $\mathrm{u}$ vidu dividendi. Jedan njegov deo mora biti zadržan $\mathrm{i}$ reinvestiran u poslovanje kao interni izvor, a u cilju finansiranja deljeg rasta i razvoja preduzeća. Finansijski menadžeri moraju oceniti finansijske efekte različitih faktora koji su relevantni sa aspekta raspodele neto dobitka na deo koji će biti akumuliran $\mathrm{i}$ deo koji treba da se isplati akcionarima $\mathrm{u}$ vidu dividende. Uzimajući u obzir dejstvo različitih faktora, organi upravljanja treba da usvoje određenu politiku raspodele, odnosno politiku akumulacija.

Ekonomski je neracionalno očekivati da preduzeće svoj rast i razvoj može finansirati isključivo angažovanjem sopstvenih izvora. Stoga, kada se radi o finansiranju kapitalnih ulaganja preduzeće se oslanja i na pozajmljene izvore finansiranja koji zajedno sa sopstvenim izvorima čine strukturu kapitala. Dugoročni kapital predstavlja sve vrste dugova preduzeća koji imaju rok dospeća duži od jedne godine. Za razliku od sopstvenog izvora kapitala, gde ne postoji obaveza vraćanja, dugoročni dug predstavlja obavezu koju preduzeće mora izmiriti u određenom roku i pod određenim uslovima koji su utvrđeni ugovorom između zajmodavca i zajmoprimca. Dugoročne dugove preduzeće angažuje kroz direktne kredite sa davaocima kredita, ili posrednim putem kroz prodaju dugoročnih hartija od vrednosti (obveznica).

Kriterijumi koji diktiraju izbor između raspoloživih izvora, sopstvenih i pozajmljenih, su brojni i veoma često se nalaze u međusobnom konfliktu, što određivanje željene finansijske strukture preduzeća čini izuzetno kompleksnim problemom. Izuzetan značaj odluka iz ovog domena nalaže potrebu da se svaka raspoloživa alternativa vezana za finansiranje preduzeća detaljno analizira sa aspekta troškova preduzeća i dugoročnih implikacija na finansijski status i rast preduzeća.

Komponovanje strukture kapitala praktično i teorijski je vrlo složen problem s obzirom da preduzeća posloju u uslovima rizika, kako poslovnog tako i finansijskog. Stepen rizika diktira nivo očekivanih prinosa. Ako je rizik veći,prinos će biti veći, i obrnuto. Kvalitet tih očekivanih prinosa se izražava $u$ obliku neto poslovnog dobitka kao prinosa na ukupna sredstva i neto dobitka kao prinosa na sopstvena sredstva. Cilj preduzeća je da minimizira ukupan rizik, odnosno da teži ka nekoj optimalnoj finansijskoj strukturi. U tu svrhu se koristi aparatura finansijskog leveridža (o kojem ćemo kasnije nešto više govoriti) kojom se traži adekvatna mešavina duga i akcijskog kapitala koja će doprineti smanjenju finansijskog rizika. Veoma često se postavlja pitanje da li postoji poseban stepen finansijjkog leveridža pri kome tržššna vrednost preduzeća može biti veća nego na drugim stepenima leveridža. To pretpostavlja da se istraži kako promene u stepenu leveridža utiču na cene i 
tržǐšne vrednosti pojedinih izvora finansiranja duga i akcijskog kapitala, zatim kako promene u cenama pojedinih izvora finansiranja utiču na prosečnu cenu kapitala, odnosno na promenu tržišne vrednosti preduzeća.

Odnos sopstvenog i pozajmljenog kapitala takođe utiče i na obezbeđenje: rentabilnosti, sigurnosti, elastičnosti i nezavisnosti preduzeća.

\section{Finansijski rizik i finansijski leveridž}

Preduzeća su u toku svoje poslovne aktivnosti izložena riziku, poslovnom i finansijskom. Ukoliko preduzeće u strukturi izvora finansiranja ima i pozajmljene izvore, ono posluje u uslovima finansijskog rizika. Iz poslovnog dobitka moraju se pokriti nastali rashodi na ime kamate, koji su fiksni na postojećem obimu proizvodnje. Usled intenzivnije promene poslovnog dobitka zbog promene obima prodaje, treba očekivati veću promenu dobitka pre oporezivanja i neto dobitka nego što je promena poslovnog dobitka. Ta promena se meri preko faktora finansijskog leveridža. Finansijski leveridž se može definisati na više načina. U prvom redu on se može definisati kao odnos duga i sopstvenih izvora. Zatim kao relativni odnos tržšne vrednosti čistog duga i tržišne vrednosti ukupnog kapitala, i kao relativni odnos efektivnih rashoda na ime kamate i poslovnog dobitka koji preduzeće ostvaruje angažovanjem i korišćenjem ukupnih poslovnih sredstava. $\mathrm{Na}$ ovakav način finansijski leveridž se definiše radi razmatranja cene kapitala i optimalne finansijske strukture preduzeća. (Ivanišević 2011:)

Faktor finansijskog leveridža $=\mathrm{Pd} /(\mathrm{Pd}-\mathrm{I})$

Pd- poslovni dobitak

\section{I- kamata}

Ukoliko u strukturi izvora finansiranja učestvuje i dug, treba očekivati da će stopa prinosa na sopstvena sredstva biti veća od stope prinosa na ukupno angažovana sredstva t $\mathrm{j}$ treba očekivati pozitivne efekte finansiranja iz pozajmljenih izvora. Ovi pozitivni efekti će se pojaviti samo u slučaju ako je kamatna stopa na pozajmljena sredstva niža od stope prinosa na ukupno angažovana sredstva. Ovde se radi o fiksnim finansijskim rashodima na ime kamate na dugove koji aktiviraju dejstvo finansijskog leveridža.

Koliko će biti povećanje neto dobitka, zavisi od strukture izvora finansiranja, odnosno od veličine duga i apsolutne razlike između kamatne stope i stope prinosa na ukupno angažovana poslovna sredstva.

Efekti finansijskog leveridža mogu biti pozitivni i negativni. Pozitivan efekat finansijskog leveridža se ostvaruje kada stopa prinosa na ukupna sredstva bude 
viša od prosečne kamatne stope, što dalje utiče da stopa prinosa na sopstvena sredstva bude viša od stope prinosa na ukupna sredstva.

Negativni efekti finansijskog leveridža će se javiti u slučaju kada je poslovni dobitak manji od rashoda ne ime kamate. Ukoliko se javi poslovni gubitak onda se faktor finansijskog leveridža ne može utvrditi. Ako bi stopa prinosa na ukupna poslovna sredstva bila jednaka prosečnoj kamatnoj stopi na pozajmljena sredstva, odnosno dugove, tada ne bi bilo ni pozitivnih ni negativnih efekata finansijskog leveridža, odnosno preduzeće će u tom slučaju ostvariti tačku indiferencije finansiranja. U ovom slučaju promena strukture kapitala ne bi imala efekta na stopu prinosa na sopstvena sredstva, a samim tim ni na tržišnu vrednost preduzeća.

\section{Analiza finansijskih izveštaja preduzeća}

Važnost sutrukture kapitala u preduzeću, odnosno odnos sopstvenog i pozajmljenog kapitala, i njegov uticaj na tržišnu vrednost preduzeća najbolje se može prikazati analizom finansijskih izveštaja. $U$ našoj analizi iskoristićemo finansijske izveštaje privrednog društva Koncern "BAMBIBANAT” a.d., Beograd.

Komponovanje strukture kapitala predstavlja veoma složen proces i zbog toga moramo da analiziramo finansijske izveštaje određenog broja godina kako bismo uporedili odnos između sopstvenog i pozajmljenog kapitala i kako se on menjao iz godine u godinu. Uporedićemo finansijske izveštaje od 2010. do 2014. godine.

Tabela 1. Podaci iz finansijskih izveštaja

\begin{tabular}{|c|c|c|c|c|c|}
\hline \multirow{2}{*}{$\begin{array}{c}\text { Vrednost kapitala } \\
\text { izražena } u \\
\text { hiljadama dinara }\end{array}$} & \multicolumn{5}{|c|}{ GODINE } \\
\hline & 2010. & 2011. & 2012. & 2013. & 2014. \\
\hline Sopstveni kapital & 3.379 .630 & 3.523 .639 & 4.246 .450 & 5.099 .691 & 6.481 .137 \\
\hline Pozajmljeni kapital & 3.322 .195 & 3.230 .341 & 4.035 .125 & 3.188 .558 & 3.086 .483 \\
\hline Ukupni kapital & 6.701 .825 & 6.753 .980 & 8.281 .575 & 8.288 .249 & 9.567 .620 \\
\hline Odnos SK i PK & $50,5: 49,5$ & $52: 48$ & $51: 49$ & $62: 38$ & $68: 32$ \\
\hline Poslovni dobitak & 1.338 .993 & 1.111 .731$. & 1.574 .717 & 1.869 .353 & 1.937 .597 \\
\hline Neto dobitak & 556.003 & 897.929 & 1.098 .494 & 1.718 .238 & 1.725 .793 \\
\hline $\begin{array}{c}\text { Rashodi na ime } \\
\text { kamata }\end{array}$ & 89.035 & 120.434 & 88.480 & 85.093 & 62.512 \\
\hline $\begin{array}{c}\text { Faktor finansijskog } \\
\text { leveridža }\end{array}$ & $1,07 \%$ & $1,12 \%$ & $1,06 \%$ & $1,05 \%$ & $1,03 \%$ \\
\hline $\begin{array}{l}\text { Stopa prinosa na } \\
\text { ukupna sredstva }\end{array}$ & $19,98 \%$ & $16,46 \%$ & $19,02 \%$ & $22,55 \%$ & $20,25 \%$ \\
\hline
\end{tabular}




\begin{tabular}{|c|c|c|c|c|c|}
\hline $\begin{array}{c}\text { Stopa prinosa na } \\
\text { sopstvena sredstva }\end{array}$ & $16,45 \%$ & $25,48 \%$ & $25,87 \%$ & $33,76 \%$ & $26,62 \%$ \\
\hline
\end{tabular}

Izvor: Agencija za privredne registre www.apr.gov.rs

\section{Sopstveni i pozajmljeni kapital}

$\mathrm{Na}$ osnovu podataka o odnosu kapitala, koji smo dobili iz finansijskih izveštaja, primećujemo promene $\mathrm{u}$ strukturi kapitala $\mathrm{iz}$ godine $\mathrm{u}$ godinu. $\mathrm{U}$ prvoj godini posmatranja odnos sopstvenog i pozajmljenog kapitala bio je gotovo izjednačen $(50,5: 49,5)$. U 2011. godini odnos kapitala povećava se u korist sopstvenog kapitala zbog toga što kamatna stopa raste i preduzeće nema ekonomske koristi od korišćenja pozajmljenih izvora, već se oslanja na sopstvene izvore finansiranja. U 2012. godini kamatna stopa opada za $1 \%$. Preduzeće povećava iznos sopstvenog kapitala za 20,5\%, ali takođe i dodatno zadužuje zbog povoljnije kamatne stope, stoga odnos između sopstvenog i pozajmljenog kapitala neznatno smanjuje. U trećoj posmatranoj godini odnos između sopstvenih i pozajmljenih izvora značajno se menja. Ukupni kapital ostaje isti, iznos sopstvenog kapitala povećava se za $20 \%$, a za isto toliko procenata se smanjuje pozajmljeni kapital. Razlog možemo videti u kamatnoj stopi (grafik 2) koja ponovo beleži rast. Zbog tih fluktuacija kamatne stope preduzeće ne želi da povećava finansijski rizik i posledica toga ogleda se $u$ većem pomeranju strukture kapitala ka sopstvenim izvorima. Na kraju, odnos između ova dva pokazatelja iznosi 62:38 u korist sopstvenih izvora finansiranja. Poslednja posmatrana godina nastavlja trend prethodne godine. Povećava se ukupni kapital za 15,5\% i ceo iznos ovog povećanja pripisuje se sopstvenom kapitalu, a pri tom se pozajmljeni kapital smanjuje za $4 \%$ u odnosu na prethodnu godinu, povećava se odnos u korist sopstvenog kapitala $\mathrm{i}$ on u 2014. godini iznosi 68:32 u korist sopstvenog kapitala.

Grafik 1. Odnos sopstvenog i pozajmljenog kapitala

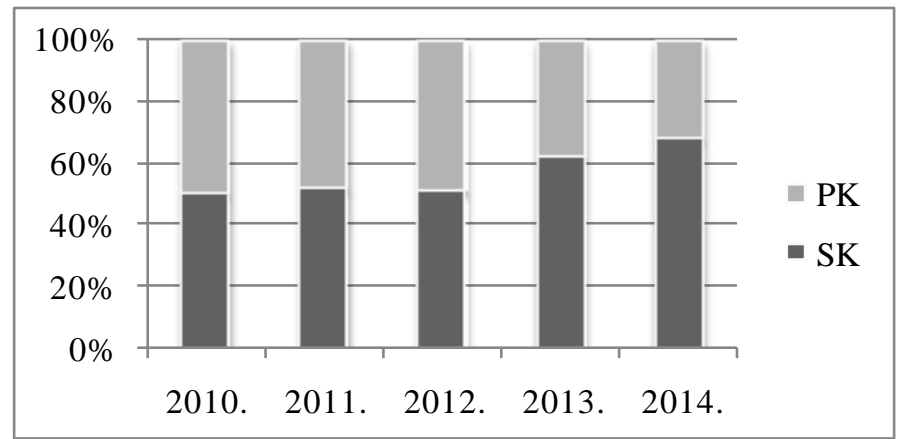


Grafik 2. Kretanje prosečne godišnje kamatne stope.

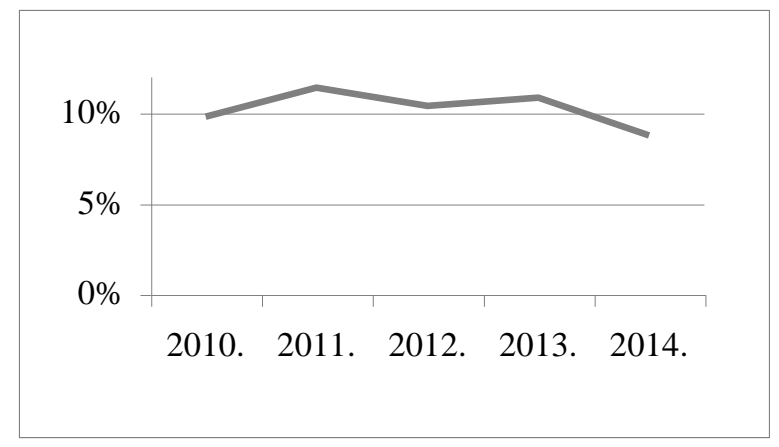

Ako bi prvu posmatranu godinu, odnosno 2010., uzeli kao baznu, možemo iz Grafika 2. videti koliko se količina osnovnog i pozajmljenog kapitala menjala u odnosu na baznu godinu.

Grafik 3. Kretanje sopstvenog i pozajmljenog kapitala u odnosu na baznu godinu

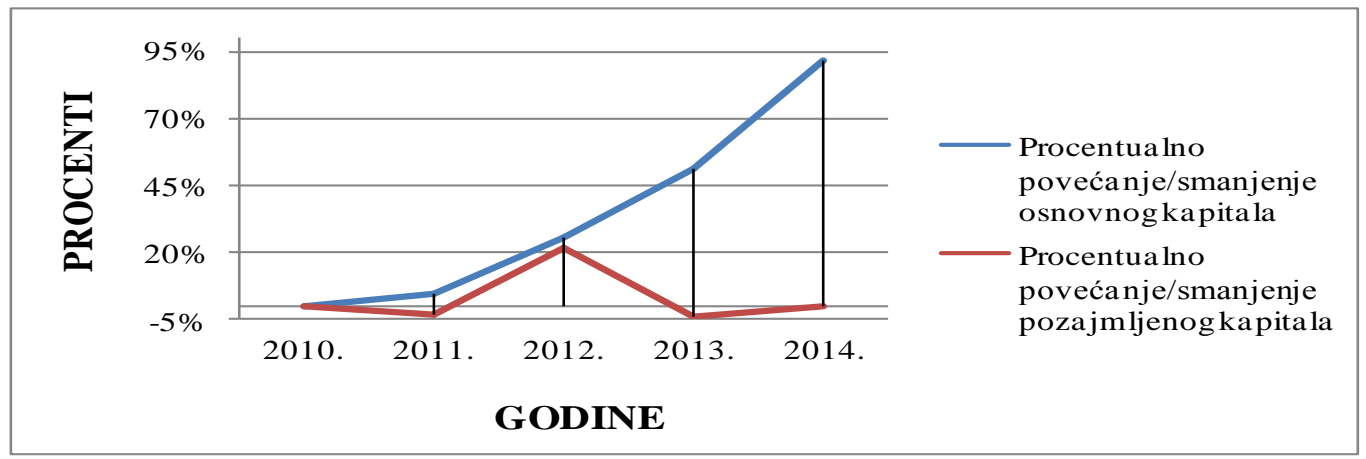

Preduzeće je za pet posmatranih godina svake godine uvećavalo svoje sopstvene izvore finansiranja i iz grafika možemo videti kako su se te stope kretale. Najveća stopa je u poslednjoj posmatranoj godini, odnosno u 2014. godini, a ona iznosi 91,77\%. Ako uporedimo ovaj grafikon sa grafikom 1 videćemo da je godina sa najvećim učešćem sopstvenog kapitala u ukupnom kapitalu ujedno i godina sa najvećom stopom rasta sopstvenog kapitala.

Kod pozajmljenog kapitala imamo malo drugačije promene u stopama nego što je to slučaj kod sopstvenog kapitala. Od bazne godine količina kapitala polako se smanjuje i samo se u 2012. godini naglo povećava, zbog toga što tu imamo pad kamatne stope, ali onda već u sledećoj, 2013. naglo opada i nastavlja taj trend opadanja pozajmljenih izvora finansiranja preduzeća. 
U odnosu na kretanje sopstvenog kapitala, gde je najveća stopa bila u poslednjoj godini, ovde je drugačije. Preduzeće je vrlo malo smanjilo učešće pozajmljenog kapitala $\mathrm{u}$ ukupnom $\mathrm{u}$ poslednjoj godini, ali je zato značajno povećalo udeo sopstvenog kapitala, što je rezultiralo da odnos između sopstvenog i pozajmljenog kapitala u 2014. godini bude 68:32 u korist sopstvenog kapitala.

\section{Poslovni i neto dobitak}

Na grafikonu 4. nalaze se krivulje koje prikazuju kretanje poslovnog i neto dobitka od 2010. do 2014. godine. Poslovni dobitak u 2011. godini beleži pad od $17 \%$, a neto dibitak rast od $61,5 \%$ u odnosu na prethodnu godinu. Neto dobitak je povećan, a uzrok toga ogleda se u povećanju kamatne stope. Ona je uticala na smanjenje pozajmljenih izvora finansiranja, a samim tim i smanjenje rashoda na ime kamate.

Grafik 4. Kretanje poslovnog i neto dobitka

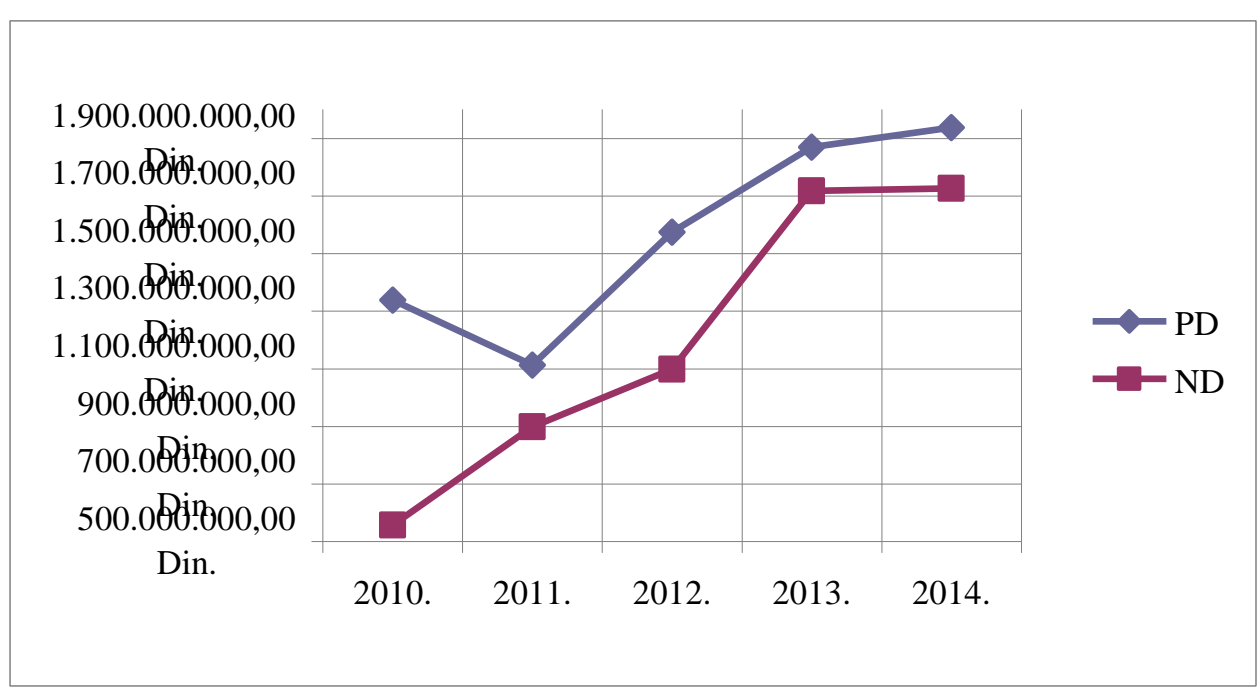

Preduzeće je još povećalo i učešće sopstvenih izvora finansiranja što je dovelo do rasta neto dibitka usled pada poslovnog dobitka. Od 2011. do 2014. godine i poslovni i neto dobitak beleže rast, što je rezultat stalnog uvećanja ukupnog kapitala i u njemu udeo sopstvenog kapitala. Preduzeće smanjuje svoje obaveze na ime kamate i ostvaruje sve veću neto dobit.

Veoma je značajna i struktura poslovnog dobitka tj. koliki njegov deo čini neto dobitak, jer to je ono što predstavlja uspešnost poslovanja jedne profitne organizacije. Taj odnos možemo videti na grafikonu 5. 
Grafik 5. Učešće neto dobitka u poslovnom dobitku

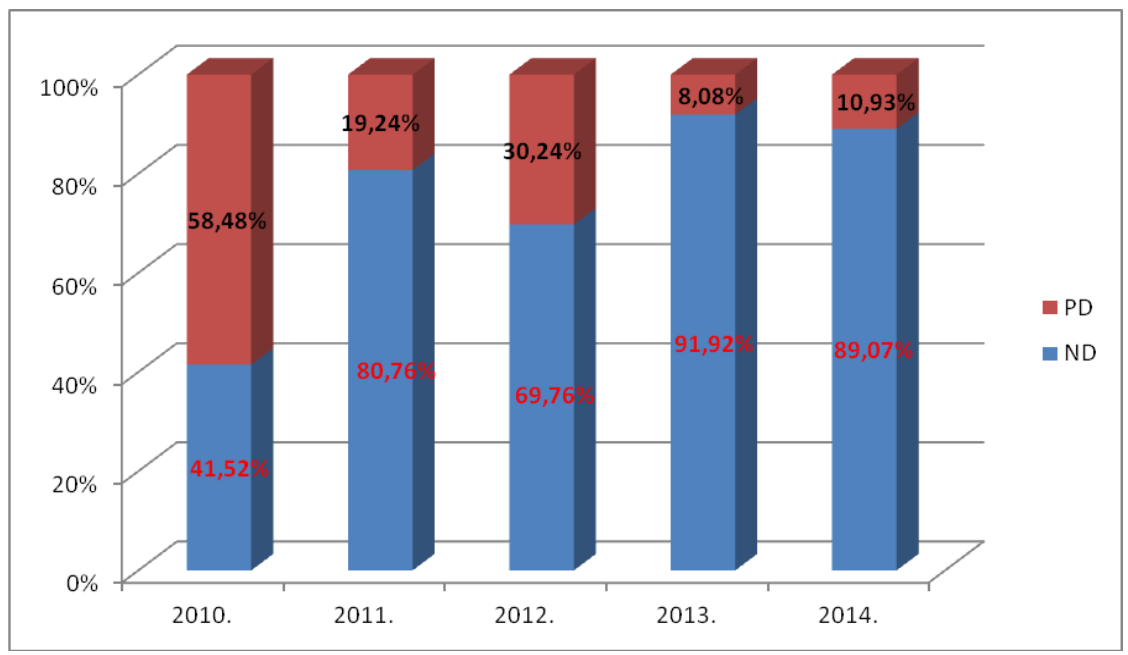

\section{Stopa prinosa na ukupna i sopstvena sredstva}

Stope prinosa predstavljaju pokazatelj koji dovodi u vezu kapital i dobitak. Stopa prinosa na ukupna sredstva stavlja u odnos poslovni dobitak i ukupni kapital, a stopa prinosa na sopstvena sredstva neto dobitak i sopstvene izvore finansiranja.

Iz tabele 1. vidimo da u strukturi preduzeća postoji dug na ime kamate i treba očekivati da stopa prinosa na sopstvena sredstva bude veća od stope na ukupna sredstva.

Na grafikonu 8. prikazano je kretanje stope prinosa na ukupna i na sopstvena sredstva. Primećujemo da je stopa prinosa na ukupna sredstva samo u prvoj godini veća od stope prinosa na sopstvena sredstva. U toj godini je učešće pozajmljenih izvora veliko, gotovo je izjednačen odnos sopstvenog i pozajmljenog kapitala. Od 2011. do 2013. godine obe veličine beleže rast, s tim što je stopa na ukupna sredstva manja od stope prinosa na sopstvena sredstva. Najveća razlika između ove dve stope je u 2013. godini, a ona iznosi $11,21 \%$. U toj godini je razlika u odnosu, između sopstvenog i pozajmljenog kapitala 62:38. U petoj posmatranoj godini obe veličine beleže pad, zbog toga što kapital beleži veći rast od dobiti, a stope prinosa proporcionalno zavise od dobitka, a obrnuto proporcionalno od kapitala. Samim smanjenjem odnosa između stopa smanjuje se i faktor finansijskog leveridža, koji je u ovoj, poslednjoj godini, najniži i iznosi $1,03 \%$. 
Grafik 6. Kretanje stopa prinosa na ukupna i sopstvena sredstva

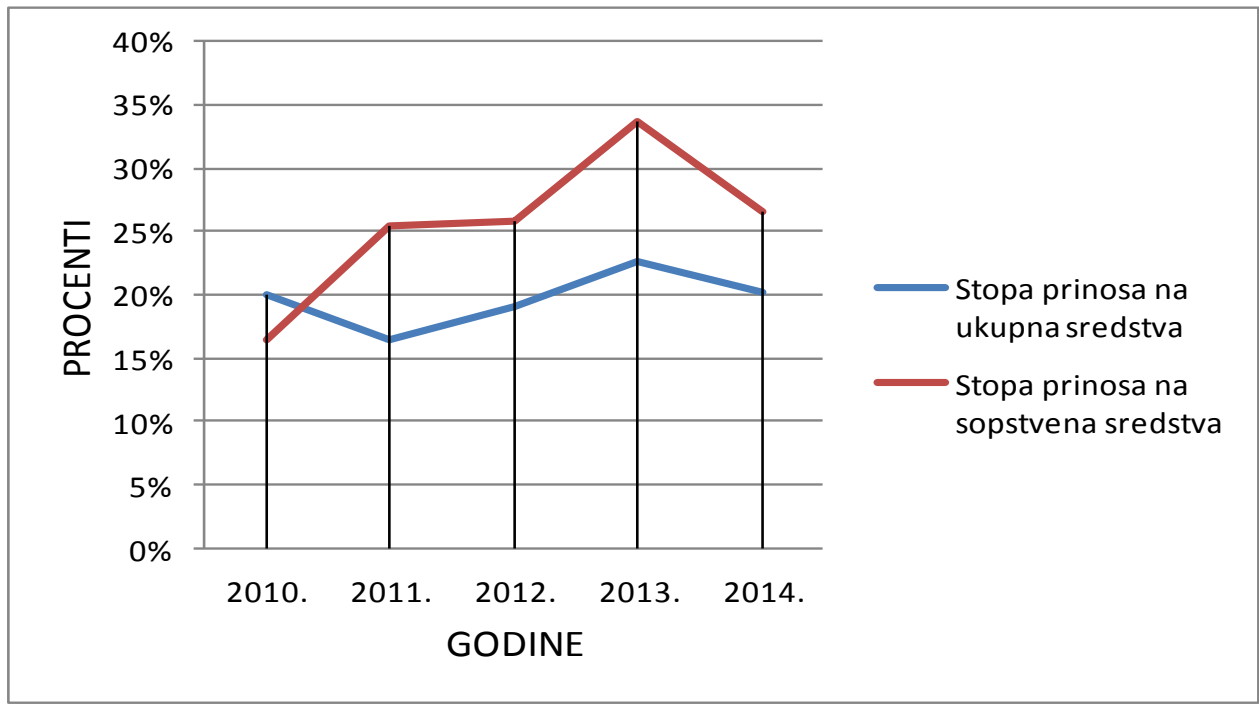

Vrednost akcija preduzeća na tržištu

$\mathrm{Na}$ slici 1. na levoj vertikalnoj lestvici nalazi se vrednost pojedinačne akcije preduzeća, a na desnoj vertikalnoj lestvici nivo izdatih akcija u periodu od 2012. do 2014. godine.

U tabeli 1. videli smo da ukupno uložena sredstva beleže konstantan rast iz godine u godinu, raste procenat učešća sopstvenog kapitala u ukupnom, a i neto dobitka, koji se odrazio na tržišnu vrednost akcija, odnosno na tržǐšnu vrednost samog preduzeća.

Slika 1. prikazuje da je vrednost akcije u 2012. godini iznosila 22.000 din. u tom periodu je odnos sopstvenog i pozajmljenog kapitala bio gotovo izjednačen. U 2013. godini vrednost akcija raste i svoj maksimum dostiže 15.09. kada je iznosila 45.000 din. Povećanje tržišne vrednosti akcije je posledica povećanja neto dobitka, a povećanje neto dobitka je bila posledica promene strukture kapitala. U 2014. godini tržišna vrednost akcija dostiže svoj maksimum, jer je u toj godini bio najveći neto dobitak i najveće učešće sopstvenog kapitala u ukupnom kapitalu. Vrednost akcije 23.01. iznosila je 68.000din, a učešće sopstvenog kapitala u ukupnom je poraslo na $68 \%$. 
Slika 1. Tržišna vrednost akcija preduzeća BAMBI

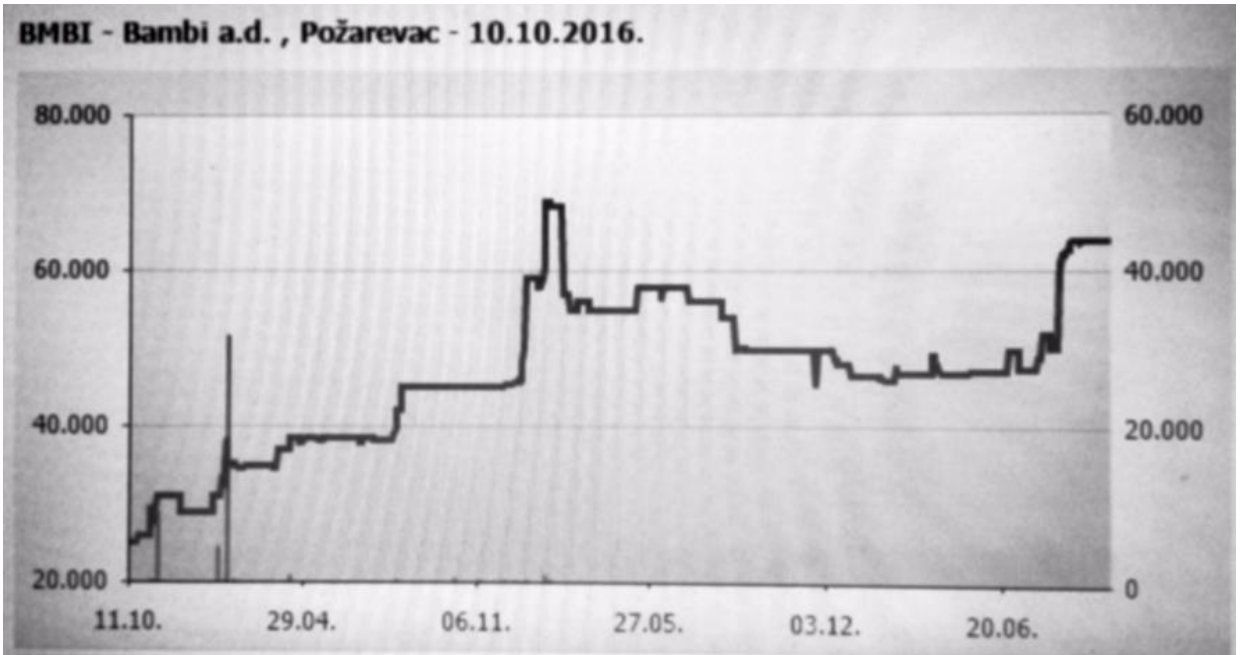

$\mathrm{Na}$ dan 01.11.2016. godine tržišna vrednost akcije iznosi 64.003 din, broj izdatih akcija 313.547. Na osnovu ova dva pokazatelja može se izračunati ukupna tržišna kapitalizacija preduzeća i ona iznosi 20.067.948.641 dinara.

\section{Zaključak}

Privredni subjekat za svoje poslovanje mora uvek imati određena sredstva, a sopstveni izvori kapitala nekada nisu dovoljni da pokriju njegove potrebe, ono mora koristiti i dodatne, odnosno pozajmljene izvore. Pozajmljivanjem kapitala preduzeće plaća određenu kamatu kao naknadu za korišćenje tuđih sredstava. Osnovni pozajmljeni izvori kapitala su: kratkoročni i dugoročni krediti, emitovanje kreditnih hartija od vrednosti i tekuće obaveze.

Preduzeće smanjuje dugove, povećava sopstveni kapital i to se odražava na veće učešće neto dobitka u poslovnom rezultatu.

\section{Literatura:}

1. Ivanišević, M. 2011. Poslovne finansije, Ekonomski fakultet, Beograd,

2. Milojević, I. 2010. Računovodstvo, Centar za ekonomska i finansijska istraživanja, Beograd

3. Krasulja, D., i Ivanišević, M. 2007. Poslovne finansije, Ekonomski fakultet, Beograd.

4. www.predavanjaets.wordpress.com (Pristupljeno sajtu 25.11.2015.) 
5. $\underline{\text { www.belex.rs }}$ (Pristupljeno sajtu 27.11.2015.)

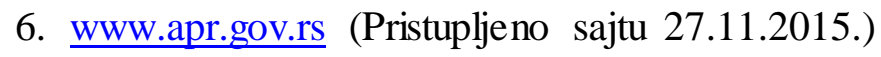

7. www.paragraf.rs/statistika/21_stat_arh.htm (Pristupljeno sajtu 26.11.2016.)

\section{CAPITAL STRUCTURE AS A DETERMINANT OF COMPANY VALUE}

\section{Nikola Milanović $^{46}$, Slobodan Andžić ${ }^{47}$, Mirko Butulija ${ }^{48}$}

\section{Apstrakt}

Profit represents the goal of every producing company. In order for a company to be able to produce a product or provide a service it must have certain capital at its disposal. There are two types of capital and it's necessary to determin their relations, how it affects the business, its profit and value. We will perform an analysis of one production company. Based on its financial reports and using the method of comparison, we will compare key parameters that will enable us to achieve the necessary information and achieved goal.

Key words: company, own capital, borrowed capital, financial risk, return rate.

46 Nikola Milanović, Defense University, Military Academy, Belgrade, Generala Pavla Jurišića Šturma no. 33, Beograd, E-mail: office@va.mod.gov.rs

47 Slobodan Andžić Ph.D., Full Professor, Belgrade Business School, Kraljice Marije no. 76, Belgrade, E-mail: s.andzic@bbs.edu.rs

${ }^{48}$ Mirko Butulija, AMS insurance, Belgrade, Ruzveltova no. 16 